\begin{tabular}{l|c|c|}
\hline DE & DE GRUYTER & ECONOMIC THEMES (2017) 55(1): 25-38 \\
$\mathrm{G}$ & DOI $10.1515 /$ ethemes-2017-0002 \\
\hline
\end{tabular}

\title{
THE FIRST STEPS TOWARD THE BANKING UNION'S IMPLEMENTATION AND EFFECTS ON THE EUROZONE BANKING SECTOR
}

\author{
Silvia Kirova \\ University of National and World Economy, Sofia, Bulgaria \\ $\bowtie$ silviakirova@yahoo.com
}

UDC

$336.7(4)$

Review

paper

Received:

10.07.2016.

Accepted:

31.01.2017.

\begin{abstract}
The banking union in Europe was proposed in 2012 as one of the key measures to address the structural weaknesses of the Economic and Monetary Union. It was introduced at a time of a serious regulatory overhaul of the financial sector in all developed parts of the world. Now that its implementation has started with the launch of the Single Supervisory Mechanism and the start of the Single Resolution Mechanism it is time to review what is the state of play of the elements of the banking union and to analyse the effects of its implementation on the Eurozone banking sector. The paper looks at each one of the pillars of the banking union. Then the author analyses the current state of the Eurozone banking sector and tries to identify how the introduction of the banking union has influenced on the developments within that sector. The paper argues that the Eurozone's banking sector has become more stable, better capitalised and its risks more controlled than in 2008 but this is at the expense of profitability. The Eurozone banking sector continues to exhibit a high level of non-performing loans. In part, this can be attributed to the banking union and the challenges it poses to the banking sector.
\end{abstract}

Keywords: banking union, supervision, resolution, deposit insurance, banks.

JEL classification: F36, F45, G21

\section{Introduction}

The banking union was conceived in 2012 to treat some of the structural flaws of the Economic and Monetary Union which only became apparent during the global financial crisis. The building of the banking union is a work in progress. With its first pillar, namely the Single Supervisory Mechanism (SSM), functioning since November 2014, the second pillar, the Single Resolution Mechanism (SRM) 
working since the beginning of 2016, and its third element, the European Deposit Insurance Scheme (EDIS) not yet established, it is worth reviewing what the immediate effects for the Eurozone banking sector are. The ultimate goal of the banking union is to provide integrity, soundness and stability of the banking sector in the Eurozone and thus contribute for the economic growth. Therefore, it is important to analyse the effects of the implementation of the banking union as to how they relate to this ultimate goal. Further to that the paper looks at the current state of each of the elements of the banking union and in the end, analyses the effects of those developments on the Eurozone banking sector as well as the condition of this sector.

The problem that is analysed here is a subject of research but since the building of the banking union started only in 2012 and the introduction of the first element dates back from 2014, that research is not extensive. Elliot (2012) authors one of the key pieces, related to the establishment of the banking union, that lays down the main principles of its establishment and treats some questions about its design and institutional infrastructure. Others, like Hadjiemmanuil (2015),Schoenmaker and Siegmann (2013), Lehmann and Nyberg (2014) treat different aspects related to the banking union and its separate pillars. The effects of the banking union on the Eurozone banking sector are treated by Bremusand Lambert (2014) and Xafa (2015).

\section{State of Play of the Banking Union}

\subsection{The Single Supervisory Mechanism (SSM)}

The Single Supervisory Mechanism came into effect in November 2014. It represents a complex interaction and responsibilities shared between the European Central Bank (ECB) and the National Competent Authorities (NCA). It is the first established and yet fully functioning pillar of the banking union. Since November 2014 The ECB is responsible for the direct supervision of 129 significant banking groups in the Eurozone whose total assets amount to about 25 trillion euro, or about $82 \%$ of the Eurozone banking assets. The remaining "less significant" banks, which are about 3500 are supervised by the national supervisors in cooperation with the ECB, as the latter can decide at any time to overtake the direct supervision over such bank.

The first task before the SSM was its institutional building, including its staffing. Since its inception, the SSM has recruited more than 1000 supervisors, coming from the 19 national supervisors, from the ECB and from the private sector. The SSM had set up the so called Joint Supervisory Teams (JSTs), each one responsible for the direct supervision of a single significant banking group. The JSTs are led by an ECB coordinator, but two thirds of their members are from the 
National Competent Authorities, and only one third from the ECB. Therefore, the larger part of the JST's members are located where the supervised bank location is. Along with the JSTs, the SSM provides for divisions with horizontal functions, spanning along all the banks, like risk analysis, authorizations or sanctions, as well as supervisors, responsible for the indirect supervision.

Another major task that was carried out during the first year and a half of functioning of the SSM was the development of common methodologies. In that respect a Supervisory Manual was drafted that provides all supervisors with a common set of procedures and practices.

In 2015, the ECB carried out the first Supervisory Review and Evaluation Process (SREP), in which all directly supervised banks were assessed against a common benchmark. In this process the ECB analyses the risks for the supervised banks and imposes prudential requirements on individual banks. The SREP consists of four components: assessment of bank's business model, an analysis of its internal governance and risk management, an analysis of the risks to the bank's capital and an analysis of the risks to the bank's liquidity and funding. Each bank gets a rating for each component and an overall rating.

Furthermore, in 2015 a comprehensive assessment was carried for nine banks, like the comprehensive assessment carried out in 2014 for all significant banks in the Eurozone, before the start of the SSM. Five of those nine banks had not passed the test and their capital shortfall amounted to 1,74 billion euro. As of November 2015, four of the five banks have covered the shortfalls. Further to that around 240 on-site inspections have been carried out in 2015 and total 1500 supervisory decisions being taken.

The challenges before the SSM, as outlined by Daniele Nouy, Chair of the Supervisory Board of the Single Supervisory Mechanism (Nouy, 2015) are related to the need for further harmonization of regulation and of supervisory practices among the 19 member states. The other big challenges are those stemming from the banking sector and the environment in which it operates, namely the low profitability of banks, the large share of non-performing loans, the regulatory changes, the stringent requirements and etc.

\subsection{The Single Resolution Mechanism}

The single resolution mechanism is the second pillar of the Banking Union, which complements the supervisory function. It is already functioning but not in full range. Its aim is to ensure that banks, that are not properly managed and have unsound business models, are allowed to fail, but this will happen in a predictable, orderly and uniform manner across the banking union and the EU as a whole. At the same time the bank resolution should bear no cost to the taxpayers as it was the case during the crisis. On the contrary, the cost should be born exclusively by the 
banks' stakeholders - shareholders and bond holders, who are the same those that enjoy the profits of that business. This second pillar is composed of two elements - the Single Resolution Board (SRB) and the Single Resolution Fund (SRF).

The Single Resolution Board, located in Brussels was established in 2015 and started operation on January 1th, 2016, along with the entry into force of the European Bank Recovery and Resolution Directive (BRRD). Since that date, SRB is responsible for the direct monitoring and resolution of the 129 significant banking groups that are directly supervised by the ECB, plus 15 cross-border banks, that have subsidiaries in more than one member state. The work programme of the SRB for 2016 outlined four main priority areas and clear objectives attached to them. Those areas are as follows: 1 . Ensuring resolution readiness; 2 . Setting up and managing the SRF; 3. Fostering and broadening cooperation; and 4. Capacity building.

As far as the first priority is concerned, the resolution planning was considered a core task for 2016. The SRB had to draw up and adopt resolution plans for the banks under its remit. A special committee is working on a Resolution Planning Manual that is going to help SRB and the National Resolution Authorities in their resolution planning activities. Another very important objective, related to that priority is the need for the SRB in consultation with the ECB to determine the minimum requirements for own funds and eligible liabilities (MREL) for those banks. This objective stems from the Bank Recovery and Resolution Directive, whose new rules require that each bank have minimum resources available at all times, that allow it to have sufficient loss-absorbing capacity if it has to be resolved. The MREL should be also aligned with the new standard for Total LossAbsorbing Capacity (TLAC), issued in November 2015 by the Financial Stability Board, which has international dimensions, extending beyond Europe. The MREL will be set for each bank, but SRB need to develop a harmonized framework for that purpose. Finally, the SRB needs to work further on identification and removal of any remaining barriers before resolvability. Such a remaining barrier is the divergent legislation in the different member states, which impedes the harmonious implementation of the BRRD, as for example the legislation about the hierarchy of claims in case of bank resolution.

As for the second priority area, the Single Resolution Fund is being gradually built up. The Single Resolution Fund complements the work of the Single Resolution Board, providing the funds needed for the restructuring of banks. The process of built-up of the SRF is envisaged to take 8 years and in 2023 the SRF should have a capacity of about EUR 55 billion, which is around $1 \%$ of the amount of covered deposits in the Euro area. In 2016, the Euro area banks will make exante contributions to the SRF for the first time. The estimates are that those contributions will amount to EUR 11,8 billion. The remaining funds will be raised gradually until 2023. The banks' contributions will initially be allocated into 
national compartments of the SRF, which will be gradually mutualised. As the funds available in the SRF during the transition period can be insufficient to cover any eventual resolution needs, the Member States have agreed on a bridge financing system in the form of national credit lines to the SRB.

The third priority relates to the need that SRB develops and fosters the cooperation with the National Resolution Authorities (NRAs) and establishes resolution colleges.

The forth priority concerns capacity building, which includes recruiting new staff, providing secure and independent IT architecture and etc. The plans are that in 2017 the SRB will be staffed with 300 professionals.

\subsection{The European Deposit Insurance Scheme (EDIS)}

The third element that complements the Banking union is a common system for deposit insurance. This element will guarantee the completeness and the integrity of the banking union as each deposited euro in the Euro area will be insured in the same manner, no matter where the bank is located. Because of the sensitivity of that element and the resources it would involve, this element is still in the phase of development, namely in the phase of legislative proposal. In June 2015 the so called "Five President's Report" was published and it clearly pointed out to the need of a common deposit insurance scheme, as a step towards a fully-fledged financial union. Further to that in November 2015 the European Commission made a legislative proposal for a European Deposit Insurance Scheme (EDIS). The proposal outlines that EDIS will be built gradually over the existing system of national deposit insurance schemes that are established under the European rules. The level of protection of the deposits will remain unchanged at the current level of EUR 100 000. The scheme will be based on a Deposit Insurance Fund which will be built on ex-ante contributions by participating banks that are risk weighted. The fund will be administered by the Single Resolution Board. The proposal sets out the three stages which the establishment of EDIS should undergo. In the first stage the scheme will function as a re-insurance mechanism on the top of the national deposit insurance schemes. It will last for 3 years until 2020. After that the system will evolve into a co-insurance arrangement with gradual mutualisation until 2024. Starting from that year EDIS will function as a common deposit insurance scheme for the Euro area.

A key concern in the establishment of EDIS is that there are still significant risks associated with the separate national banking sectors. The underlying idea is that before the EDIS starts to guarantee the deposits on a Euro area basis, those national specific risks are mitigated. That is why the Commission proposal not only provides for the clear path towards the EDIS, but specifies the measures, needed to reduce the risks. Those measures include: harmonization of national DGS, reducing 
the national options and discretions in the application of prudential requirements on banks, greater convergence in the insolvency law and most importantly - initiatives on prudential treatment of bank' exposures to sovereign risk. The last issue is considered to be the most controversial one and is a source of concern not only for the European regulators but for global regulators as well. The so called "home bias" in portfolio holdings of banks, i.e. the large share of national government debt securities in the banks" portfolios is seen as a "fundamental source of asymmetry in the degree of risk facing the national banking sectors"(Angeloni, 2016).As per the current legislation the sovereign bonds are considered risk free and thus no risk weights or large exposure limits are attached to them, while at the same time they proved to be far from riskless assets. Therefore, a change in that respect is needed, but it should take into consideration the role that those instruments have in the financial system. The Basle Committee on Banking Supervision has already started an initiative in that area, which may produce an international standard that should be complied by in Europe as well. The view of the sector is that there should be no rigid limits or sudden imposition of new measures but flexible approach and gradual implementation, like gradually increasing risk weights to exposures concentrated on different sovereigns. The result should be not a reduction in the overall share of sovereign bonds in the bank's portfolios but greater diversification and proper assessment of the associated risks.

\section{Current Developments in the Eurozone Banking Sector and Effects from the Banking Union Implementation}

Method of Analytical Hierarchy Process (AHP) was developed by Thomas Saaty in early seventies. The AHP is a tool in the analysis of decision-making, designed to assist decision makers in solving complex problems involving a larger number of decision-makers, as well as numerous criteria.

The implementation of the banking union in Europe goes hand in hand and its effects can't be easily delimited from the impact of the fundamental regulatory overhaul of the banking sector that is taking place after 2008 on a global scale. This fundamental regulatory reform was initiated to address the vulnerabilities that had piled up in the financial sector for decades, to bring back and to guarantee the financial stability. The global dimensions of the financial crisis in 2008 provoked a global and coordinated response from the policymakers in several dimensions - the quantity and quality of the banks' capital, addressing the systemic risk through macroprudential regulation, the resolution of banks with cross-border activities, the "too big to fail" issue, the incentives structure and others.

As measured against the purpose of creating stability it can be said that the regulatory changes, including the establishment of the banking union in Europe 
have made a tremendous step at achieving that goal. As of 2016, compared to 2008 a significant progress has been achieved in terms of less risk and more control in the banking sector. The overall capitalisation of banks in the Euro area has increased, as well as the capacity of banks to absorb shocks. The banks in the European union continue to strengthen their capital position and in June 2016 the common equity tier 1 (CET1) ratio of European banks in 13,6\%. For comparison, the CET 1 ratio of Euro area significant banks was around 7\% in 2007 and 9\% in 2012. The interconnectedness is better controlled. The compliance and the risk management has become a core function in the banking sector.

Unfortunately, those goods have not come for free and in that case, they have been achieved at the expense of profitability. In 2015, the return on equity (ROE) of the banks, directly supervised by the ECB have increased to $4,5 \%$ compared to $2,8 \%$ in 2014 . Despite this positive development, the return on equity is still very low compared to the pre-crisis level (about 15\%), as well as compared to the current ROE of the all US banks (about $9 \%$ in 2015). The ROE of Eurozone banks is low for a prolonged period of time and the problem is that since 2008 the ROE stands below the cost of capital for the banks, which stands around $9 \%$ for the significant banks.

The low profitability of the Eurozone banks and the modest prospects in that respect are determined by cyclical and structural factors. Among the cyclical factors one can point out the subdued outlook for the economic growth on a global level and for the Eurozone, in particular, and the low interest rate environment which reduces the interest earnings of banks. The low profitability can be further explained by the high stock of non-performing loans in the region which determines high loan-loss provisions. Other factors contributing for the low profitability are the growing direct and indirect costs of risk management and compliance and the big amount of litigation costs for some of the big banks. According to the data, provided by the European Banking Authority in its Risk Assessment Report for December 2016, more than 44\% of the banks in the European Union have paid more than EUR 500 million in compensation, litigation and similar payments since the financial 2007/2008 year. The share of the banks that have paid more than EUR 1 billion in such costs is $37 \%$.

Another source of concern is the big stock of non-performing loans in the Eurozone. As mentioned above they require high loan-loss provisions and hamper the banks' capacity to extend new loans. The NPL ratio for the Eurozone has decreased modestly in 2015 to $6,7 \%$. As can be seen on the graph below (Figure 1) this level is quite higher than the level of NPLs reported by the World Bank for the other developed economies, USA and Japan, which is below 2\% for 2015. 
Figure 1. Bank nonperforming loans to total gross loans, 2006-2015, (\%)

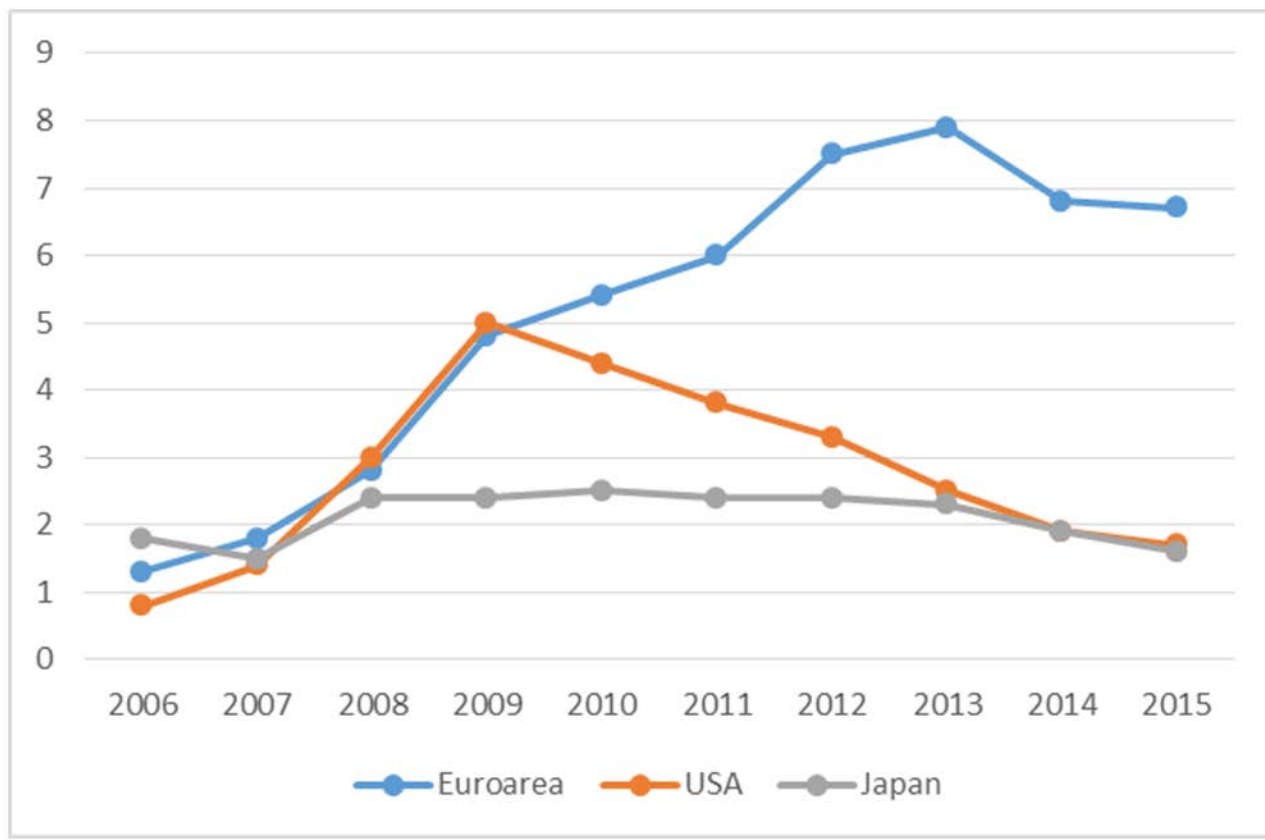

Source: World BankOpen Data Web Page, http://data.worldbank.org/indicator/FB.AST.NPER.ZS?view=chart.

The NPLs ratios vary significantly from country to country as the crisis-hit countries show highest ratios, as per the data of the European Banking Authority. For example, the NPL ratio for Greece and Cyprus are 43,5\% and 50\% respectively as of September 30, 2015. The level of NPLs in Ireland (20,6\%), Portugal (18,5\%), Italy (16,9\%) and Slovenia (16\%) are also very high. In the other end are countries line Sweden, Finland and Luxemburg, showing the lowest level of NPLs - 1\%, $1,4 \%$ and $1,5 \%$ respectively. As far as the whole European Union is concerned, one third of its member countries have an NPL ratio above $10 \%$ in the second quarter of 2016.

As far as the lending activity of banks is concerned, the latest ECB Bank Lending Survey points out to a recovery of loan growth in the Eurozone, driven both by increase in supply and demand of loans. In April 2016 loans to households have grown at $1,5 \%$ on an annual basis and loans to non-financial corporations have grown by $1,2 \%$. The survey also indicates an easing of bank lending standards for loans to enterprises and consumer credit, while at the same time the loan standards for lending to households for home purchases have tightened. Overall the credit standards are tighter than their historical range as of 2003. The banks, participating in the survey assess that the retail funding conditions have remained unchanged, and for wholesale funding, the access to debt securities have 
deteriorated but to securitization improved. The banks report that they have used the liquidity provided by the ECB's asset purchase programme to increase lending, but this programme had negative impact on their profitability. A contributing factor to the increase in lending was the ECB's negative rate on the deposit facility.

Given these developments in 2015 one can judge that the Eurozone banking sector is improving but still facing the challenges of low profitability and high stock of non-performing loans. The assessment of those challenges and risks led to a deterioration of the market sentiment towards the Eurozone banking sector during the short market turmoil in the beginning of 2016. During the last 12 months, the Eurozone bank stocks lost about $30 \%$ of their value, most of which in the beginning of the year. Although the episode was short-lived and its effects contained, it showed the vulnerability of the banking sector and the way the market evaluated its risks. As far as the deterioration of market sentiment is concerned it is also reflected in the reduced issuance volume of unsecured debt in the first three quarters of 2016 compared to 2015, although the funding costs are low due to the accommodative monetary policies. Heightened volatility on funding markets resulted in increased fluctuations of spreads for unsecured debt. Overall is ca be said that the market sentiment towards the European banks remains deteriorated and the markets skepticism stems from the greater challenges before the banks to restore profitability and to adapt to a new post-crisis business model.

Apart from these current developments there should be noted some structural weaknesses of the Eurozone banking sector and economic model as well. Compared to other developed countries the Eurozone economy is much more dependent on the banking sector for financing its needs. In the USA for example the bank credit for the real economy is about a half of its GDP and the capital markets play much more important role. In some Eurozone countries, like Netherlands and Spain, the bank credit to the real economy is about twice their GDP, and in Germany, France, Italy is about the size of the economy. Despite the decrease of deleveraging in the past years, the size of the banking sector in the Eurozone in terms of bank credit to the real economy as a share of GDP and banking assets as a share of GDP, remains very high. This highlights the dependence of the Eurozone economy on the developments in the banking sector and therefore the high market sensitivity to those developments. The undertaking of the Capital Markets Union is a major step that should assure that capital markets in Europe play much more important role for financing the economy than they play now and potentially decrease the dependence on banks. But its creation is a difficult task, comparable to and even harder than the creation of the banking union and one should not expect its effects very soon.

There are indications that the Eurozone banking sector suffers from overcapacity as well. The low ROE is such an indication, demonstrating, among other things that there are many banks with similar business models that are 
working in an environment of tight competition. The fierce competition and the thin profit margins may urge some banks to take excessive risk. Thus, as Bremus and Lambert (2014) indicate, in case the overcapacity is not properly adjusted and banks do not manage to develop sustainable business models in the medium turn, this may have a negative impact for the stability of the financial system.

Following this general overview of the developments in the Eurozone banking sector, it is worth trying to identify the effects and the challenges, stemming directly from the banking union implementation.

The first thing that should be noted is that the implementation of the banking union is associated with direct costs imposed on the banks. The supervision and regulation are expensive goods. In 2016 for example the banks in the Eurozone should pay EUR 404 million supervisory fees to the ECB and will have to contribute for a first time to the Single Resolution Fund with contributions, reaching EUR 11,8 billion.

Except for those direct costs, the banking union comes with indirect costs as well. If we start with the first pillar, the Single Supervisory Mechanism, the market participants agree that the ECB as a single supervisor is a "game changer", but there are doubts that its policy as a supervisor is inconsistent and goes contrary to its monetary policy function. The critics argue that while the ECB is trying to stimulate the economic growth by the quantitative easing programme, the same ECB is imposing stricter capital requirements above the regulatory minimum (via the SREP), and thus affects growth negatively. As a result of the SREP in 2015 the banks that are directly supervised by the ECB faced in 2016 capital requirements that are by 30 basis point higher than the previous year, which should be added to the 20 basis points increase due to phase-in of macroprudential buffers. This makes a total increase of 50 basis points. Although this can be considered as a smooth transition to full Basle III implementation, it places the Eurozone significant banks in an unfavorable position compared to their rivals in the developed world.

As long as the Single Resolution Mechanism is concerned it should be stressed that the new bank crisis management framework in Europe represents a complete shift in the philosophy as to how bank failures should be handled. The big worry that bank failures result in government debt and taxpayers' losses seems to be eliminated. The link between bank debt and government debt is broken. But didn't the regulators create a problem elsewhere? Are the shareholders and senior unsecured bond holders ready and able to bear the risk of bank failures and at what price?

The recent episode of market turmoil in the beginning of 2016 was provoked by factors outside the banking sector but it was greatly affected because of the concerns, associate with it, including the concern of the market as to how the new bail-in rules will be implemented. Those rules were somewhat tested in December 
2015, just a month before they entered into force, as the Portugal's central bank wiped out five bonds of Novo Banco's balance sheet amounting to billions of euros and moved them to the so called "bad bank". This provoked the negative reaction of the bondholders (big institutional investors) but also the negative reaction of the investors as a whole, realising the shift in the political mood and the new risks associated with investments into banks. Once deemed very safe instruments, now the investments in bank bonds are as risky as an investment in non-financial corporate bonds. This will inevitably translate into an increase in the bank fundraising costs and further on the cost of bank loans to the economy and the households.

The new requirements in the BRRD provide that creditors should be bailed-in, including senior debt holders up to the amount of $8 \%$ of total liabilities including own funds, before the Single Resolution Fund can be accessed. The senior debt includes senior unsecured bonds, corporate deposits and liabilities from derivative contracts. At the same time the rules give preferential treatment to insured deposits and uninsured deposits of small and mid-sized enterprises and households. The problem is now that the different member states still have different legislation regarding the hierarchy of claims, i.e. who should be bailed-in and who should be saved in case of resolution. On one hand, it is imperative to change that and introduce uniform hierarchy for the whole banking union, but on the other hand, amending the current situation can potentially have redistributive effect among existing creditors and create disadvantages for banks when complying with the new requirements, as stated by the Chair of the Single Resolution Board in a recent hearing before the European Parliament (Koenig, 2016). The market participants also point that the lack of uniform treatment can make the bank resolution across border more complex and the fund raising for banks more difficult and costly.

Another test for how the new bank resolution rules work will be the Italian banking crisis. The banks in Italy show a high rate of non-performing loans and although it is not the highest number (other countries have higher rates of NPL), the fact that Italy is the third economy in the Eurozone and that the amount in real terms is enormous makes the problem very serious. The volume of nonperforming loans is about EUR 360 billion, bigger than the volume the banks' equity. In case the new bank resolution rules are applied very strictly, before the Italian government can step in and provide capital injection to the banking system, the bank subordinated debt holders will first have to bear losses. For years the Italian banks have sold their shares and bonds to their retail customers therefore the banks shareholders and bondholders are primarily households and not investment companies. Thus, the rigid application of the new resolution rules which were designed to save the taxpayers from losses will result in a such situation where thousands of retail investors will suffer from the bail-in. Here, the European regulators have to show some flexibility and allow Italy to protect the retail 
bondholders up to a certain level. Otherwise, instead of preventing crisis the new resolution regime may be in the position of creating crisis.

Last but not least, there are challenges, stemming from the third pillar of the banking union. The hard negotiations around it and the opposing views of the different member states on how to structure this third element are indication for those challenges. It seems that there is now a political will to overcome the opposing views and achieve a single deposit insurance as a step towards complete Economic and Monetary Union. Leaving the work half-done and the banking union incomplete may create uncertainty and risks and pose doubts on the ability to pose the European priorities above the national interests.

\section{Conclusion}

The establishment of the banking union in Europe is a major step and the most radical reform of the Economic and Monetary Union since the beginning of the global financial crisis. It is not surprising, because of the significant role that the banks in Europe have for the real economy. This reform takes place in the context of a regulatory overhaul of the financial sector on a global scale, affecting the banks in the other centers of the developed world as well.

While the rationale for creating a banking union is clear and undoubted, it should be admitted that its implementation can pose certain challenges for the banking sector. Two years after the start of its implementation some of those challenges are obvious. The banking sector is better capitalized and more stable, more regulated and the risks more controlled. But the banking sector bears huge and costly regulatory burden. There are concerns that the new rules will make the bank fundraising more expensive. The big negative result is the destroyed profitability of the banking sector in the Eurozone. Although this may be a legacy of the debt crisis, there are serious concerns as to whether the rule based supervision isn't pushed too far and too aggressively. It still not clear whether those rules, will be able to produce viable, profitable and globally competitive Eurozone banks, along with the stability they provide.

\section{References}

Angeloni, I. (2016) European banks and the banking union, Remarks by the member of the ECB's Supervisory Board at the European American Economic Forum organized by Euronext and the European American Chamber of Commerce, New York, June 7, 2016.

Bremus, F. and C. Lambert (2014) Banking Union and Bank Regulation: Banking Sector Stability and Europe (DIW Economic Bulletin 9/2014). 
Elliott, D. (2012) Key issues on European banking union: Trade-offs and some recommendations(Global Economy and Development, Working paper 52, November 2012).

European Banking Authority, Risk Assessment of the European Banking System, December 2016.

European Central Bank (2016) Financial Stability Review, May 2016.

European Central Bank (2016) Euro area Bank Lending Survey, April 2016.

Hadjiemmanuil, C. (2015) Bank Resolution Financing in the Banking Union (LSE Law, Society and Economy, Working Paper 6/2015).

Hamoir, O. (2016) The impact of regulatory reform on the European banking sector, Speech at the Bruegel 10th anniversary celebrations, Brussels, January 28, 2016.

Junker, J., Tusk, D., Dijsselbloem, J., Draghi, M. and Schulz, M. (2015) Completing Europe's Economic and Monetary Union, European Commission, June 22, 2015.

Koenig, E. (2016) Briefing, Hearing with Mrs. E. Koenig, Chair of the Single Resolution Board, ECON Committee, European Parliament, January 28, 2016.

Lehmann, A. and L. Nyberg (2014) Europe's Banking Union in the Global Financial System: Constructing Open and Inclusive Institutions (EBRD Working Paper 175/2014).

Mesnard, B., Margerit, A., Power, C. and Magnus, M. (2016) Non-performing loans in the Banking Union: stocktaking and challenges, Briefing prepared for Economic Governance Support Unit, Directorate-General for Internal Polices, European Parliament, March 18, 2016.

Nouy, D. (2015) The Single Supervisory Mechanism after one year: the state of play and the challenges ahead, Speech by the Chair of the Supervisory Board of the SSM, Banca d' Italia conference "Micro and macroprudential supervision in the euroarea", UniversitaCattolica, Milan, November 24, 2015.

Schenmaker, D. and A. Siegmann (2013) Winners of a European Banking Union, Retrieved from:Centre for European Policy Research Portal: http://voxeu.org/article/winnerseuropean-banking-union, Accessed on September 16, 2016.

Xafa, M. (2015) European Banking Union Three Years On (GIGI Papers 73/June 2015).

\section{PRVI KORACI KA IMPLEMENTACIJI BANKARSKE UNIJE I UTICAJI NA BANKARSKI SEKTOR EVROZONE}

Apstrakt: Bankarska unija u Evropi je predložena u 2012. kao jedan od ključnih mera za rešavanje strukturnih slabosti ekonomske i monetarne unije. Uvedena je $\mathrm{u}$ vreme ozbiljnog regulatornog sređivanja finansijskog sektora $\mathrm{u}$ svim razvijenim delovima sveta. Sada kada je njena implementacija počela sa lansiranjem jedinstvenog nadzornog mehanizama i početka jedinstvenog mehanizma rezolucije vreme je da se razmotri kakvo je stanje elemenata bankarske zajednice i da se analiziraju efekti njegove primene na bankarski sektor Evrozone. U radu se razmatra svaki od stubova bankarske zajednice. Autor analizira trenutno stanje bankarskog sektora Evrozone i pokušava da identifikuje kako je uvođenje bankarske unije uticalo na dešavanja u tom sektoru. U radu se ističe da bankarski sektor Evrozone postaje sve stabilniji, 
bolje kapitalizovan i njegovi rizici su više pod kontrolom nego u 2008. godini, ali na račun profitabilnosti. Bankarski sektor Evrozone i dalje pokazuje visok nivo nenaplativih kredita. Jednim delom, to se može pripisati bankarskoj zajednici i izazovima koje postavlja pred bankarski sektor.

Ključne reči: bankarska unija, nadzor, rezolucija, osiguranje depozita, banke.

\section{Author's biography}

Silvia Kirova is a Senior Assistant Professor at the International Economic Relations and Business Department of the University of National and World Economy in Sofia. She holds a PhD degree from that university since 2012 for a dissertation on The Nominal and Real Convergence between the Euroarea Member States. Her scientific interests are in the field of the monetary and financial integration in Europe, financial markets post-crisis regulation, global financial stability and etc. She has published papers and participated in scientific conferences with materials on the above topics. Many of her recent publications are devoted to the establishment of a banking union in Europe and its effects. 